\title{
Whitening Effect of Hizikia fusiformis Ethanol Extract and Its Fractions
}

Myong Je Jeon', Mihyang Kim², Hye-Ji Jang', Seung-Woo Lee', Jae-Hoon Kim³, Hyung-Suk Kim ${ }^{3}$ and Sang-Hyeon Lee ${ }^{1}$ *

${ }^{1}$ Department of Bioscience and Biotechnology, Graduate School, Silla University, Busan 617-736, Korea

${ }^{2}$ Department of Food and Nutrition, Silla University, Busan 617-736, Korea

${ }^{3}$ Haeim Pharmetic Co, Marine-Bio Center, Busan 617-736, Korea

Received February 14, 2012 /Revised July 10, 2012 /Accepted July 20, 2012

\begin{abstract}
Melanin synthesis is catalyzed by tyrosinase. To investigate the whitening effect of Hizikia fusiformis, fractions from ethanol extract of $H$. fusiformis were prepared by a systematic fractionation procedure with solvents such as methanol, hexane, butanol, and $\mathrm{H}_{2} \mathrm{O}$. The ethanol extract and its fractions were then subjected to evaluate the inhibitory effects on the tyrosinase activity and melanin synthesis in murine B16F10 melanoma cells. The ethanol extract and aqueous fraction exhibited a whitening effect with no cytotoxicity. The ethanol extract showed the highest whitening effect among the samples. The inhibitory effect of $100 \mu \mathrm{g} / \mathrm{ml}$ of ethanol extract was higher than that of $10 \mu \mathrm{g} / \mathrm{ml}$ of arbutin, but it was lower than that of $10 \mu \mathrm{g} / \mathrm{ml}$ of kojic acid. Furthermore, the inhibitory effects of $100 \mu \mathrm{g} / \mathrm{ml}$ of methanol, hexane, butanol, and aqueous fractions were similar to those of $10 \mu \mathrm{g} / \mathrm{ml}$ of arbutin. The antioxidant activities were examined by comparing the results with that of ascorbic acid as a positive control. The ethanol extract and aqueous fraction showed relatively higher DPPH radical-scavenging activities compared with the other samples. Furthermore, $500 \mu \mathrm{g} / \mathrm{ml}$ of ethanol extract and aqueous fraction diminished LPS-induced iNOS expression to 82 and $80 \%$, respectively. These results suggest that ethanol extract and aqueous fraction of $H$. fusiformis could be used as cosmetic ingredients for whitening and skin protection effects.
\end{abstract}

Key words : Hizikia fusiformis, melanin, tyrosinase activity, whitening effect

\section{서 론}

멜라닌은 자외선으로부터 피부를 보호하는 역할을 하지만 과도하게 생성될 경우 피부에 색소가 침착되어 기미와 주근깨 를 형성하며, 심할 경우 피부암의 원인이 되기도 한다[9]. 따라 서, 피부의 색소 침착 현상을 방지하지 위해서는 멜라닌 생성 과정의 일부분을 저해하여 멜라닌 생성을 감소시켜야 한다. 멜라닌은 동 · 식물과 미생물계에 널리 존재하는 페놀류의 고 분자 천연색소로 표피 기저층에 존재하는 melanocyte 내의 melanosome에서 합성된다[30]. 멜라닌은 L-tyrosine의 연속 적인 산화반응으로 합성되는데, L-tyrosine은 tyrosinase에 의 해 3,4-dihydroxyphenylalanine (L-DOPA)으로 전환되고, L-DOPA는 phenylanine-3,4-quinone으로 산회되며, 중간 대 사산물을 거쳐 최종적으로 멜라닌이 된다[32]. 따라서, 피부미 백과 관련된 기능성 화장품의 소재를 개발하기 위해서는 그 물질이 tyrosinase의 활성을 저해하는지의 여부가 중요하다 [7]. 현재까지 멜라닌 색소의 생합성을 저해하는 물질에 관한 연구는 주로 tyrosinase의 활성을 저해하는 수준에서 이루어 져 왔으며 저해제로는 hydroquinone, ascorbic acid, 4-hy-

*Corresponding author

Tel : +82-51-999-5624, Fax : +82-51-999-5636

E-mail : slee@silla.ac.kr droxyanisole, kojic acid, azelaic acid, arbutin, corticosteroids 등이 보고되고 있으나, 안전성 및 경제성 등의 문제점으로 사 용이 제한되고 있다 $[1,14,22,24,33]$. 따라서, 화장품 업계에서는 기존의 미백소재가 가지고 있는 이러한 단점을 극복하기위해 최근에는 상백피, 짝자래나무, 포도씨 및 피트모스 추출물 등 의 천연물을 활용한 화장품소재의 개발을 위한 연구가 활발히 진행되고 있으며, 피부에 안전하면서 미백효과가 뛰어난 소재 의 개발에 대한 요구가 증가하고 있다[7,10,17,29].

최근 우리나라는 생활수준의 향상으로 건강한 삶과 노화에 대한 관심이 증가하면서 웰빙(well-being) 및 웰에이징 (well-aging)의 개념이 확대되고 있는 추세이다. 특히, 화장품 산업에는 생리활성 성분이 첨가된 기능성 화장품의 개념이 도입되어, 산업적으로 많이 사용되고 있다[21]. 기능성 화장품 은 화장품 기술에 생명공학 기술을 접목시켜 피부미용뿐 만아 니라 노화예방 작용도 가질 수 있는 화장품군으로, 노령인구 의 증가에 따른 삶의 질 향상에 대한 사회적 욕구를 충족시킬 수 있는 제품으로 인식되고 있다[5]. 이러한 기능성 화장품의 개발을 위해서는 소비자가 원하는 활성과 안전성을 가진 원료 물질의 개발이 우선되어야 한다[11]. 천연물질 중에는 여러 가 지 생리활성을 가진 물질이 많이 존재하여 이에 대한 연구가 활발히 진행되고 있으며, 기능성 화장품 소재로 활용되고 있 
다. 최근, 천연물의 생리활성 검색은 육상생물 대상뿐만 아니 라 해양생물 대상으로도 활발히 이루어지고 있으며, 특히, 해 조류의 생리활성 성분들에 대한 연구가 활발히 진행되고 있다 [27]. 해양생물은 독특한 환경으로 인하여 육상생물에 없는 특 유의 대사과정을 가지고 있어 다양한 신규 생리활성 물질의 탐색 가능성이 높다. 또한, 해양생물에 대한 연구는 육상생물 에 대한 연구에 비해 아직 그 수가 많지 않아서 새로운 천연물 질의 개발에 대한 기대가 높은 편이다[15].

톳(Hizikia fusiformis)은 갈조식물(Phaeophyta)문 모자반과 의 바닷말로 우리나라의 서해안, 남해안 및 제주도에 서식하 는 천연자원 식물이다[3]. 톳은 식이섬유가 풍부하고 혈액응고 작용, 면역증강작용 등의 기능성이 있는 것으로 알려진 중성 다당류인 라미나란(laminaran)과 함황산성 다당류인 푸코이 단(fucoidan)을 다량 함유하고 있다[8,16]. 톳에 대한 기존의 연구로는 미생물 번식효과[23], 지질대사 개선효과 및 항암효 과 등이 있다[13,19].

본 연구에서는 식용 해조류인 톳의 에탄올 추출물을 제조하 고, 용매의 극성에 따라 분획물을 제조하고 멜라닌생성 억제 활성 및 tyrosinase 저해활성 등을 검증하여 피부 미백활성을 가진 기능성 화장품소재로의 활용 가능성을 검토하였다.

\section{재료 및 방법}

\section{재료}

본 실험에 사용한 톳은 국내에서 자생 또는 양식되는 생시 료를 구입하여 부착물을 제거하고 수세 및 건조시킨 후 분쇄 한 다음 밀봉하여 보관하면서 사용하였다.

\section{시료의 제조}

톳(Hizikia fusiformis)의 건조분말시료에 10 배량 $(\mathrm{w} / \mathrm{v})$ 의 $80 \%$ ethanol을 첨가하여 $80^{\circ} \mathrm{C}$ 에서 8 시간 동안 추출을 행하였 으며, 추출액을 지름 $150 \mathrm{~mm}$ 의 여과지(Advantec, Japan)로 2회 여과하고 동결건조하여 에탄올 추출시료를 제조하였다. 에탄올 추출시료를 다시 methanol, hexane, butanol, $\mathrm{H}_{2} \mathrm{O}$ 등 을 이용하여 Fig. 1에 나타낸 방법으로 분획을 행한 후, speed vacuum evaporation으로 농축하고 동결건조하여 각각의 용 매에 대한 분획물을 제조하였다.

\section{Mushroom tyrosinase 저해 활성 측정}

$50 \mathrm{mM}$ sodium phosphate (pH 6.8) buffer $155 \mu \mathrm{l}$ 에 $50 \mathrm{mM}$ L-DOPA (Sigma, USA) 기질액 $25 \mu 1$ 와 검증 시료용액 $10 \mu 1$ 를 첨가하고 잘 혼합한 후, mushroom tyrosinase $(50$ units $/ \mathrm{ml}$, Sigma, USA) $10 \mu 1$ 를 첨가하고 $25^{\circ} \mathrm{C}$ 에서 2분간 반응시켜 생성 된 DOPA chrome을 $475 \mathrm{~nm}$ 에서 흡광도를 측정하였다. 양성 대조군으로 kojic acid (Sigma, USA)와 arbutin (Sigma, USA) 을 사용하였다.

\section{세포배양}

본 연구에 사용된 생쥐의 B16F10 흑색종(melanoma) 세포 는 한국세포주은행(Korean Cell Line Bank, KCLB, Seoul, Korea)에서 분양받아 사용하였다. B16F10 세포를 $10 \%$ feal bovine serum (FBS, BioWhittaker, Walkersville, $\mathrm{MD}, \mathrm{USA}$ )과 penicillin-streptomycin (100 units/ml, BioWhittaker)을 포함 하는 DMEM (BioWhittaker) 배지를 이용하여 $37^{\circ} \mathrm{C}, 5 \% \mathrm{CO}_{2}$ 에 서 배양하였다.

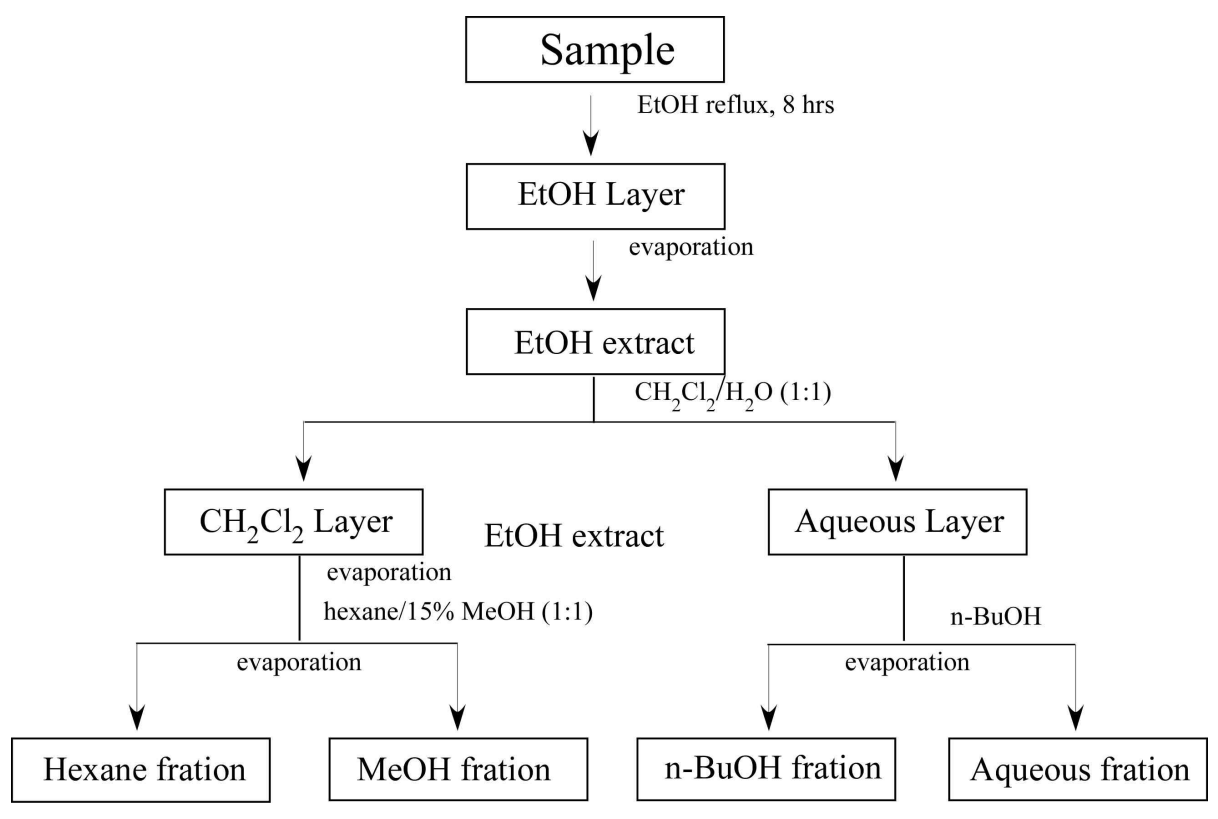

Fig. 1. Procedure of extraction and fractionation of Hizikia fusiformis. 


\section{MTT assay를 이용한 세포독성 측정}

배양이 끝난 세포의 생존율은 Chung 등이 사용한 3[4,5-dimethylthiazole-2yl]-2,5-diphenyl-tetrazolium bromide (MTT, Sigma, USA) 환원 방법을 이용하여 측정하였다[4]. B16F10 세포를 96 well plate에 well당 $1 \times 10^{4}$ 개의 세포를 접종 하고 24 시간 동안 $37^{\circ} \mathrm{C}, 5 \% \mathrm{CO}_{2}$ 세포배양기에서 배양한 후 검증 시료용액 $10 \mu \mathrm{l}$ 를 첨가하고 24시간 동안 배양하였다. 여 기에 MTT 용액 $(5 \mathrm{mg} / \mathrm{ml}) 10 \mu \mathrm{l}$ 와 배지 $90 \mu \mathrm{l}$ 를 첨가하여 동일 한 배양 조건으로 4 시간 동안 배양하여 배지를 제거하고 세포 를 phospaate buffered saline (PBS, BioWhittaker)으로 2회 세 척하였다. 각 well당 $10 \%$ DMSO $200 \mu$ 를 첨가하여 $570 \mathrm{~nm}$ 에 서 흡광도를 측정하였다.

\section{멜라닌 생성 저해 활성 측정}

배양된 B16F10 세포(배지 $2 \mathrm{ml}$ )에 $200 \mathrm{nM}$ 의 농도로 $\mathrm{a}-$ melanocyte stimulating hormone (MSH, Sigma, USA)를 처리 하고 검증 시료용액 $10 \mu \mathrm{l}$ 를 첨가하여 48 시간 배양하였다. 그 후 배지를 제거하고 PBS $2 \mathrm{ml}$ 로 2번 세척한 후, 다시 PBS 1 $\mathrm{ml}$ 를 첨가하여 세포를 긁어내어 $4{ }^{\circ} \mathrm{C}, 1,700 \times g$ 에서 5 분간 원심 분리를 행하였다. 세포 침전물에 $1 \mathrm{~N} \mathrm{NaOH}(10 \% \mathrm{DMSO})$ $200 \mu 1$ 를 첨가하여 현탁시킨 후, 96 well plate에 옮겨 $405 \mathrm{~nm}$ 에서 흡광도를 측정하였다. 양성 대조군으로 kojic acid (Sigma, USA)와 arbutin (Sigma, USA)을 사용하였다.

\section{세포내 tyrosinase 저해 활성 측정}

배양된 B16F10 세포(배지 $2 \mathrm{ml}$ )에 $200 \mathrm{nM}$ 의 농도로 $\mathrm{a}$ -MSH (Sigma, USA)를 처리하고 검증 시료용액 $10 \mu \mathrm{l}$ 를 첨 가하여 48시간 배양하였다. 그 후 배지를 제거하고 PBS $2 \mathrm{ml}$ 로 2번 세척한 후, 다시 PBS $1 \mathrm{ml}$ 를 첨가하여 세포를 긁어내 어 $4^{\circ} \mathrm{C}, 1,700 \times g$ 에서 5 분간 원심분리를 행하였다. 세포 침전 물에 lysis buffer (50 mM sodium phosphate ( $\mathrm{pH}$ 6.8) buffer, $1 \%$ Triton X-100, $0.1 \mathrm{mM}$ PMSF) $55 \mu \mathrm{l}$ 를 첨가하여 세포 를 용해시킨 후, 얼음에 30 분간 방치하고 $4{ }^{\circ} \mathrm{C}, 1,700 \times \mathrm{g}$ 에서 5 분간 원심분리를 행하고 상층액을 회수하였다. 상층액 $50 \mu$ 1 에 $50 \mathrm{mM}$ sodium phosphate $(\mathrm{pH}$ 6.8) buffer $125 \mu \mathrm{l}$ 와 기질 용액인 $50 \mathrm{mM} \mathrm{L-DOPA} \mathrm{(Sigma,} \mathrm{USA)} 25 \mu 1$ 를 넣고 $37^{\circ} \mathrm{C}$ 에 서 1시간 반응시킨 후, $475 \mathrm{~nm}$ 에서 흡광도를 측정하였다. 양 성 대조군으로 kojic acid (Sigma, USA)와 arbutin (Sigma, USA)을 사용하였다.

\section{$\mathrm{DPPH}$ 자유 라디칼 소거능 측정}

1,1-Diphenyl-2-picrylhydrazyl (DPPH, Sigma, USA)은 $\mathrm{MeOH}$ 에 녹여 $1.5 \times 10^{-4} \mathrm{M} / \mathrm{ml}$ 의 농도가 되게 제조하였다. 농 도별로 희석한 검증 시료용액 $50 \mu \mathrm{l}$ 와 $\mathrm{DPPH}$ 용액 $200 \mu \mathrm{l}$ 를 균일하게 혼합한 다음 실온에서 30 분간 방치한 후 $520 \mathrm{~nm}$ 에서 흡광도를 측정하였다. 양성 대조군으로 ascorbic acid (Sigma, USA)를 사용하였다.

\section{LPS 유도 iNOS 발현 저해효과 검증}

RAW264.7/pGL2-Neo-miNOS_pro11 세포[18]를 $60 \mathrm{~mm}$ dish에서 24시간 동안 배양하였다. 배지를 제거하고 배양 세포 를 PBS로 세정한 후 LPS (최종농도 $1 \mu \mathrm{g} / \mathrm{ml}$ )를 첨가한 다음 검증 시료용액 $5 \mu \mathrm{l}$ 를 첨가하여 $37^{\circ} \mathrm{C}, 5 \% \mathrm{CO}_{2}$ 에서 24 시간 배양 하였다. 세포 추출물의 luciferase 활성 측정은 luciferase assay kit (Promega, WI, USA)를 사용하여 제조사의 manual을 토대 로 행하였으며, TD-20/20 Luminometer (Turner Design, Sunnyvale CA, USA)를 이용하여 측정하였다. 모든 luciferase 활성측정 결과는 $\mathrm{BCA}$ protein assay reagent (Pierce, Rockford, IL, USA)로 측정한 세포 추출물의 단백질 함량으로 표준화하였다.

\section{결과 및 고찰}

\section{톳 추출물 및 분획물의 수율}

본 실험에서 사용한 해조류인 톳을 흐르는 물에 세척하고 건조시킨 후 분쇄기로 분쇄하였다. 건조된 분말시료 $500 \mathrm{~g}$ 을 ethanol로 $80^{\circ} \mathrm{C}$ 에서 8 시간 동안 추출하고 농축시킨 후 동결건 조시켜 $108.5 \mathrm{~g}$ 의 톳 에탄올 추출물을 획득하였다. 얻어진 추 출물의 성분을 그림 1 과 같이 극성과 비극성으로 분획하고 농축시킨 후 동결건조시켜 메탄올 분획물 $5.1 \mathrm{~g}$, 헥산 분획물 $3.7 \mathrm{~g}$, 부탄올 분획물 $3.8 \mathrm{~g}$, 수층 분획물 $4.1 \mathrm{~g}$ 을 획득하였다. 톳 에탄올 추출물의 수율은 $21.7 \%$ 로 나타났고, 분획물의 수율 은 3.4 4.7\%의 범위였고 메탄올 분획물이 가장 높게 나타났다 (Table 1).

\section{Mushroom tyrosinase에 대한 저해활성}

멜라닌 생성에 중요한 역할을 하는 효소인 tyrosinase에 대 한 저해 활성은 mushroom tyrosinase를 효소원으로 하여 기 질인 L-DOPA와의 반응으로 생성된 L-dopaquinone의 흡광도

Table 1 Yields (\%) of extract and various solvent fractions of Hizikia fusiformis

\begin{tabular}{|c|c|c|c|}
\hline Extraction method & Yield (\%) & Fractions & Yields (\%) \\
\hline \multirow{4}{*}{$80^{\circ} \mathrm{C}, 8 \mathrm{hr}$, ethanol } & \multirow{4}{*}{21.7} & Hexane & 3.4 \\
\hline & & Methanol & 4.7 \\
\hline & & Butanol & 3.5 \\
\hline & & Aqueous & 3.8 \\
\hline
\end{tabular}




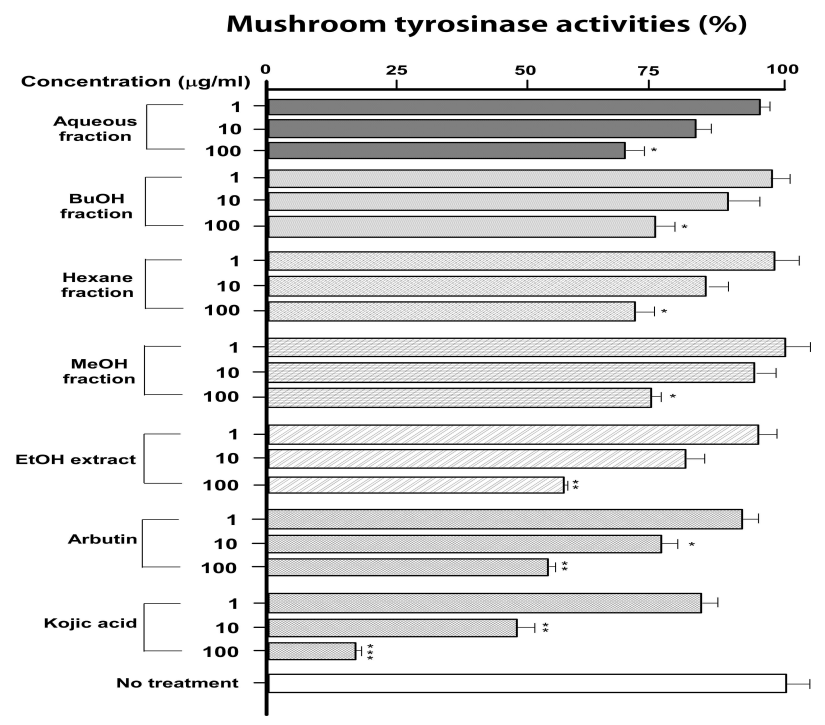

Fig. 2. Mushroom tyrosinase inhibitory activities of ethanol extract and solvent fractions of Hizikia fusiformis. Means \pm SEM for three wells are shown as fold compared with no treatment. Factorial ANOVA with Fisher's PLSD post-hoc test * $p<0.05,{ }^{* *} p<0.01,{ }^{* * *} p<0.001$ compared with no treatment. This experiment was repeated at least twice yielding reproducible results.

로 측정하였다[25]. 측정결과, 톳 에탄올 추출물은 $100 \mu \mathrm{g} / \mathrm{ml}$ 의 농도에서 음성 대조군에 비해 통계적으로 유의하게 mushroom tyrosinase의 활성을 $44 \%$ 억제하였다(Fig. 2). 가장 높은 저해활성을 나타낸 톳 에탄올 추출물은 $100 \mu \mathrm{g} / \mathrm{ml}$ 의 농도에 서 양성 대조군인 arbutin $100 \mathrm{\mu g} / \mathrm{ml}$ 의 농도와 유사한 저해활 성을 나타냈지만, 또 다른 양성 대조군인 kojic acid $10 \mu \mathrm{g} / \mathrm{ml}$ 의 농도보다 낮은 저해활성을 나타냈다(Fig. 2). 또한, 톳 에탄 올 추출물은 $10 \mu \mathrm{g} / \mathrm{ml}$ 의 농도에서 arbutin $10 \mu \mathrm{g} / \mathrm{ml}$ 의 농도 보다 조금 낮은 저해활성을 나타냈다(Fig. 2). 한편, 톳의 메탄 올, 헥산, 부탄올 및 수층 분획물들은 $100 \mathrm{\mu g} / \mathrm{ml}$ 의 농도에서 음성 대조군에 비해 통계적으로 유의하게 효소활성을 각각 $25 \%, 27 \%, 23 \%$ 및 $27 \%$ 억제하였다(Fig. 2). 특히, 수층 분획물 은 $10 \mu \mathrm{g} / \mathrm{ml}$ 의 농도에서도 통계적으로 유의하게 $16 \%$ 의 저해 활성을 나타냈지만, 4 가지 분획물 모두 $1 \mu \mathrm{g} / \mathrm{ml}$ 의 농도에서는 통계적으로 유의한 저해활성을 나타내지 않았다(Fig. 2). Kim 등은 피트모스 추출물이 $100 \mathrm{\mu g} / \mathrm{ml}$ 의 농도에서 $27 \%$ 의 mushroom tyrosinase 저해활성을 나타낸다고 보고하였고[17], Kim 등은 정공피 추출물이 $100 \mathrm{ug} / \mathrm{ml}$ 의 농도에서 $14.9 \%$ 의 저해활 성을 나타낸다고 보고하였다[20]. Shin은 홍경천, 인삼, 갈근, 오미자, 연교, 홍화씨, 창출 추출물이 $100 \mathrm{ug} / \mathrm{ml}$ 의 농도에서 각각 $19 \%, 13 \%, 10 \%, 20 \%, 19 \%, 18 \%, 14 \%$ 의 mushroom tyrosinase 저해활성을 나타낸다고 보고하였다[31].

\section{세포 생존율에 미치는 영향}

톳의 추출물과 분획물이 B16F10 세포에 대해 독성을 나타

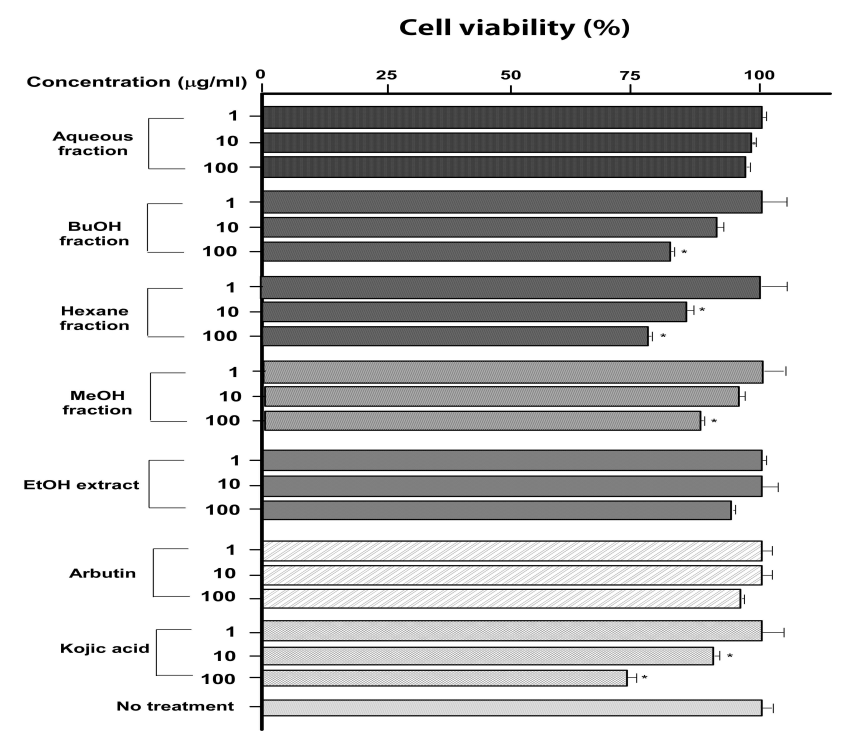

Fig. 3. Cytotoxic effects of ethanol extract and solvent fractions of Hizikia fusiformis in B16F10 cells. Means \pm SEM for three wells are shown as fold compared with no treatment. Factorial ANOVA with Fisher"s PLSD post-hoc test * $p<0.05$ compared with no treatment. This experiment was repeated at least twice yielding reproducible results.

내는지의 여부를 조사하기 위하여 시료를 다양한 농도로 1 일 동안 세포에 처리하고 MTT법으로 세포의 생존율을 조사하였 다. 그 결과, 톳 에탄올 추출물은 $1,10,100 \mathrm{\mu g} / \mathrm{ml}$ 의 모든 농도 에서 통계적으로 유의한 세포 독성을 나타내지 않았고, 톳 수 층 분획물 역시 모든 농도에서 통계적으로 유의한 세포 독성 을 나타내지 않았다(Fig. 3). 한편, 메탄올, 헥산 및 부탄올 분획 물들은 $100 \mu \mathrm{g} / \mathrm{ml}$ 의 농도에서 통계적으로 유의하게 세포 독 성을 나타냈다(Fig. 3). 양성 대조군인 kojic acid의 경우는 10 $\mu \mathrm{g} / \mathrm{ml}$ 의 농도에서도 통계적으로 유의하게 세포독성을 나타 냈다(Fig. 3).

\section{세포내 멜라닌생성 저해활성}

$\mathrm{B} 16 \mathrm{~F} 10$ 세포에 각 시료를 처리한 후, 멜라닌생성 저해활성 을 측정한 결과, 톳 에탄올 추출물은 $100 \mu \mathrm{g} / \mathrm{ml}$ 의 농도에서 음성 대조군에 비해 통계적으로 유의하게 멜라닌 생성을 $26 \%$ 저해하는 것으로 나타났고, 톳 수층 분획물은 $100 \mu \mathrm{g} / \mathrm{ml}$ 의 농도에서 통계적으로 유의하게 $18 \%$ 저해하였다(Fig. 4). 가장 높은 저해활성을 나타낸 톳 에탄올 추출물은 $100 \mathrm{\mu g} / \mathrm{ml}$ 의 농 도에서 양성 대조군인 arbutin 및 kojic acid $100 \mu \mathrm{gg} / \mathrm{ml}$ 의 농도 보다 낮은 저해활성을 나타냈지만, arbutin 및 kojic acid 10 $\mu \mathrm{g} / \mathrm{ml}$ 의 농도보다는 높은 저해활성을 나타냈다(Fig. 4). Yoon 등은 갈조류인 곰피로부터 phlorotannin 물질인 phloroglucinol, dioxinodehydroeckol 및 7-phloroeckol을 분리, 정 제하였으며, 이 중 7-phloroeckol이 가장 높은 미백활성을 나 타내어 $100 \mu \mathrm{M}$ 의 농도에서 B16F10 세포의 세포내 멜라닌 생 


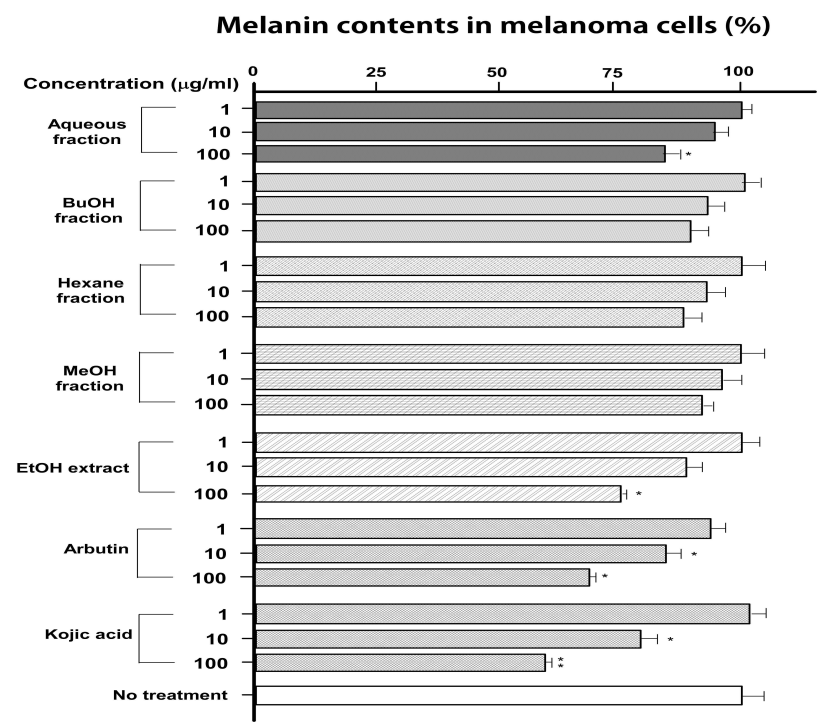

Fig. 4. Whitening effects of ethanol extract and solvent fractions of Hizikia fusiformis in B16F10 cells. Means \pm SEM for three wells are shown as fold compared with no treatment. Factorial ANOVA with Fisher"s PLSD post-hoc test * $p<0.05,{ }^{* *} p<0.01$ compared with no treatment. This experiment was repeated at least twice yielding reproducible results.

성을 $52 \%$ 저해한다고 보고하였다[37]. 본 연구에서 사용한 톳 역시 갈조류에 속하는 해조류이므로 추가 실험을 통하여 톳으 로부터 7-phloroeckol의 분리 정제 및 미백활성의 확인이 필요 할 것으로 사료된다.

\section{세포내 tyrosinase 저해활성}

B16F10 세포의 세포내 tyosinase 저해활성을 측정한 결과, 톳 에탄올 추출물은 $100 \mu \mathrm{g} / \mathrm{ml}$ 의 농도에서 음성 대조군에 비 해 통계적으로 유의하게 $40 \%$ 의 저해활성을 나타냈으며, 10 $\mu \mathrm{g} / \mathrm{ml}$ 의 농도에서도 통계적으로 유의하게 $20 \%$ 의 저해활성 을 나타냈다(Fig. 5). 또한, 톳의 메탄올, 헥산, 부탄올 및 수층 분획물들은 $100 \mu \mathrm{g} / \mathrm{ml}$ 의 농도에서 음성 대조군에 비해 통계 적으로 유의하게 각각 $18 \%, 22 \%, 20 \%, 23 \%$ 의 저해활성을 나 타냈다(Fig. 5). 가장 높은 저해활성을 나타낸 톳 에탄올 추출 물은 $10 \mu \mathrm{g} / \mathrm{ml}$ 의 농도에서 양성 대조군인 arbutin 및 kojic acid $10 \mu \mathrm{g} / \mathrm{ml}$ 의 농도보다 낮은 저해활성을 나타냈지만, 100 $\mu \mathrm{g} / \mathrm{ml}$ 의 농도에서는 arbutin $10 \mu \mathrm{g} / \mathrm{ml}$ 의 농도보다 높은 저해 활성을 나타냈다(Fig. 5). Ha 등은 찔레의 잎과 뿌리의 에탄올 추출물이 $100 \mu \mathrm{g} / \mathrm{ml}$ 의 농도에서 각각 $26 \%$ 와 $29 \%$ 의 저해활성 을 나타낸다고 보고하였고[6], Jeong 등은 우산고로쇠나무 수 피 추출물이 $200 \mu \mathrm{g} / \mathrm{ml}$ 의 농도에서 $37 \%$ 의 저해활성을 나타낸 다고 보고하였다[12].

피부는 자외선에 노출되면 tyrosine에서 출발하여 일련에 산화 중합 반응을 거쳐 생성된 melanin에 의해 기미, 노인성

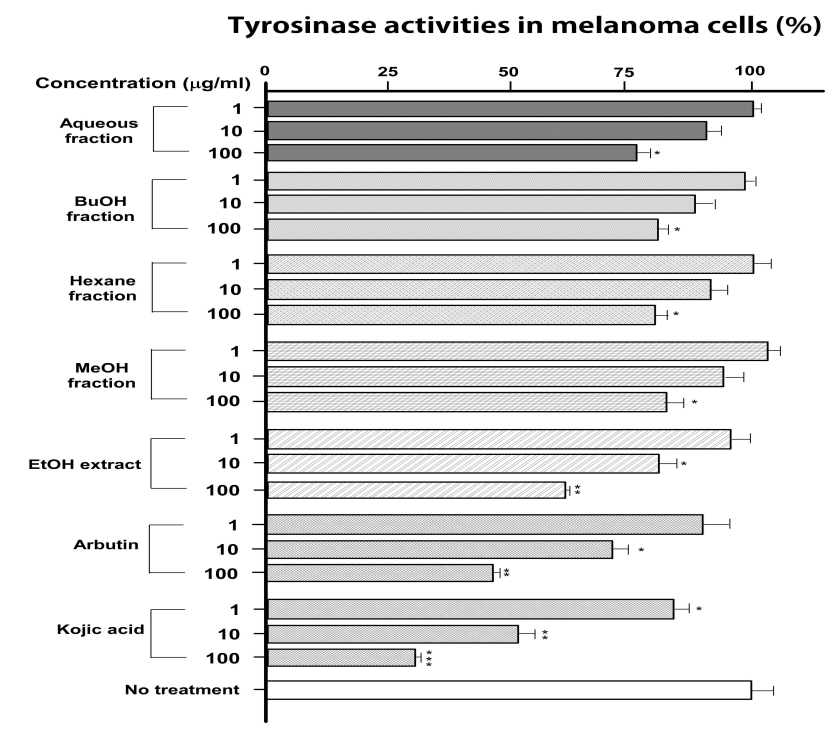

Fig. 5. Tyrosinase inhibitory activities of ethanol extract and solvent fractions of Hizikia fusiformis in B16F10 cells. Means \pm SEM for three wells are shown as fold compared with no treatment. Factorial ANOVA with Fisher"s PLSD post-hoc test * $p<0.05$, ** $p<0.01,{ }^{* * *} p<0.001$ compared with no treatment. This experiment was repeated at least twice yielding reproducible results.

홍반 등을 유발하며 피부노화가 촉진된다. 이 과정에서 중요 하게 작용하는 효소가 tyrosinase이며, tyrosinase 효소의 활 성억제로 멜라닌 생합성을 억제할 수 있는 것으로 알려져 있 다. 따라서 톳 에탄올 추출물 및 수층 분획물은 tyrosinase 활 성을 억제시킴으로서 피부 색소 침착 등을 방어할 수 있는 미백 기능성 화장품의 소재로 이용 가능할 것으로 기대된다 (Fig. 5).

\section{$\mathrm{DPPH}$ 자유 라디칼 소거능}

피부는 외부 환경에 노출되어 있는 신체 기관으로서 자외선 에 의한 영향을 직접 받는다. 자외선은 피부에 활성산소종을 유발시키고 그 결과 피부세포의 손상, 색소 침착을 증가시키 게 되며 이는 직접적인 피부 노화로 이어진다[36]. DPPH는 화합물 내 질소 중심의 라디칼로 라디칼 전자의 비편재화에 의해 안정한 구조의 라디칼로 존재한다. $\mathrm{DPPH}$ 는 $517 \mathrm{~nm}$ 에서 최대 흡수를 나타내며, 환원되면 $517 \mathrm{~nm}$ 에서 흡수가 없어지므 로 $\mathrm{DPPH}$ 의 환원정도는 환원제의 환원력에 달려있다[26].

톳 추출 및 분획 시료의 항산화 활성을 검증하기 위하여 양성대조군인 BHT (butyl hydroxy toluen, Sigma, USA), Gallic acid (Sigma, USA), Ascorbic acid (Sigma, USA)와 비교 하여 $\mathrm{DPPH}$ 의 수소 공여능을 측정하였다. 그 결과, 톳 에탄올 추출물의 $5,000 \mu \mathrm{g} / \mathrm{ml}$ 의 농도에서 $93 \%$ 의 라디칼 소거능을 나 타냈다(Fig. 6). 시료들 중에서 가장 높은 소거능을 나타낸 톳 에탄올 추출물은 $5,000 \mathrm{\mu g} / \mathrm{ml}$ 의 농도에서는 양성대조군인 


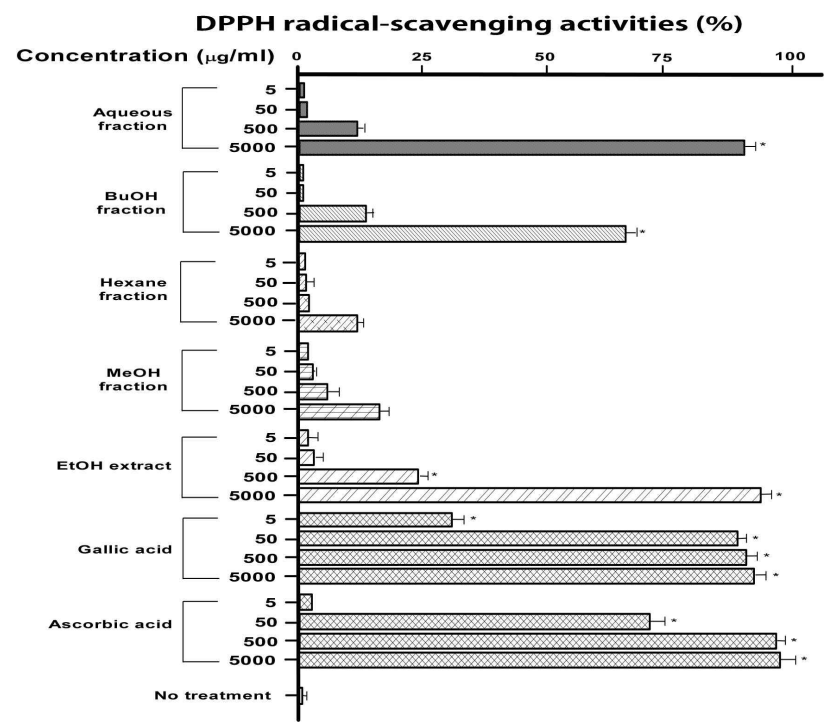

Fig. 6. DPPH radical scavenging activities of ethanol extract and solvent fractions of Hizikia fusiformis. Means \pm SEM for three wells are shown as fold compared with no treatment. Factorial ANOVA with Fisher"s PLSD post-hoc test ${ }^{*} p<0.001$ compared with no treatment. This experiment was repeated at least twice yielding reproducible results.

ascorbic acid 및 gallic acid의 동일 농도와 유사한 소거능을 나타냈지만, $500 \mu \mathrm{g} / \mathrm{ml}$ 의 농도에서는 동일 농도의 양성 대조 군보다 낮은 소거능을 나타냈다(Fig. 6). 톳 수층 및 부탄올층 분획물은 $5,000 \mu \mathrm{g} / \mathrm{ml}$ 의 농도에서 통계적으로 유의하게 각각 $90 \%$ 및 $66 \%$ 의 소거능을 나타냈다(Fig. 6). 이 중 톳 수층 분획 물은 $5,000 \mu \mathrm{g} / \mathrm{ml}$ 의 농도에서 같은 농도의 양성대조군인 ascorbic acid 및 gallic acid와 유사한 소거능을 나타냈다(Fig. 6). 따라서 $\mathrm{DPPH}$ 자유 라디칼 소거능의 측정결과, 톳 에탄올 추출물 및 수층 분획물을 항산화 소재로 활용이 가능하다는 것을 확인할 수 있었다.

\section{In vitro iNOS 발현 검출 시스템을 이용한 LPS 유도성 iNOS 발현 저해효과 검증}

다양한 생리적 기능에 관여하는 nitric oxide $(\mathrm{NO})$ 가 과도하 게 생성될 경우 세포를 사멸시키는 것으로 알려져 있다. NOS (nitric oxide synthase)는 $\mathrm{NO}$ 의 합성효소로서 정상 조건에서 항상 발현되는 constitutive형(cNOS)과 면역반응에 의해 발현 되는 inducible형(iNOS)으로 나뉜다[34]. iNOS는 활성화된 다 양한 세포에서 유도되어 병리생태학적으로 중요한 역할을 한 다[35,28]. NOS의 과다 발현은 뇌손상이나 퇴행성 뇌 신경질 환의 신경독성과 밀접한 관련이 있다고 알려져 있다[2].

톳 추출 및 분획 시료의 면역 활성을 검증하기 위하여 양성 대조군인 saponin (Sigma, USA)과 비교하여 LPS 유도성 iNOS 발현 저해효과를 측정하였다. RAW264.7/pGL2-

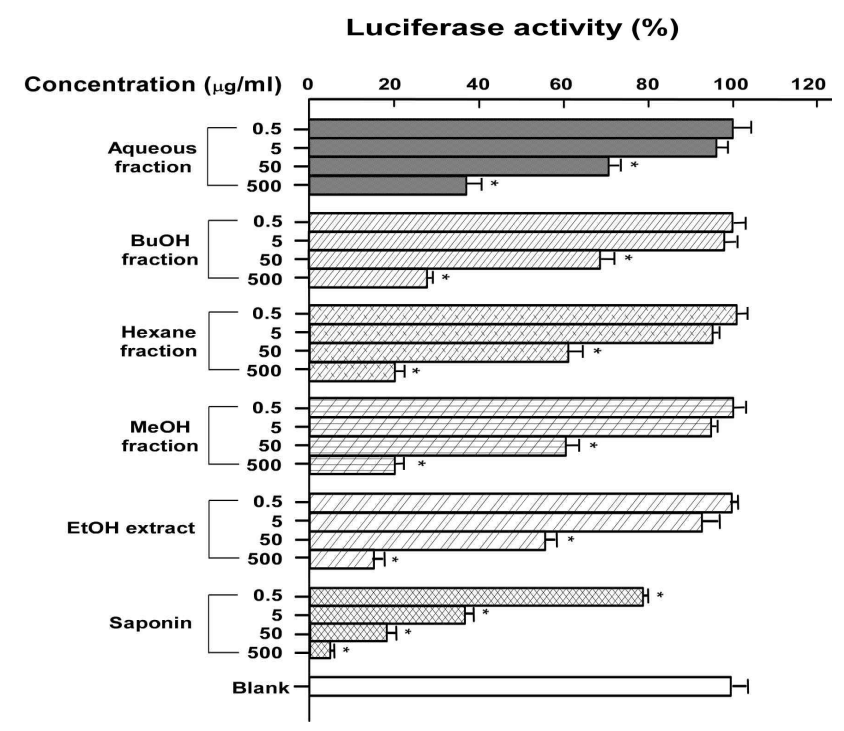

Fig. 7. Suppressive effects of Hizikia fusiforme ethanol extract and solvent fractions on LPS-induced iNOS expression using the in vitro detection system. RAW264.7/ pGL2-Neo-miNOS_pro11 cells were exposed with LPS (final concentration: $1 \mathrm{\mu g} / \mathrm{ml}$ ) and then treated with indicated concentrations of Hizikia fusiforme ethanol extract. Luciferase activity was measured using a luciferase assay kit and normalized to the protein concentration of cell lysates. The values were expressed a percentage of maximum activity in the culture treated with LPS alone. Means \pm SEM for three plates are shown. *ANOVA $p<0.0001$ compared with LPS alone (blank).

Neo-miNOS_pro11 세포에 LPS를 처리하여 iNOS 발현을 유 도한 후 톳 에탄올 추출물 및 용매 분획물을 처리하여 활성을 측정한 결과, LPS 만을 처리하여 $\mathrm{iNOS}$ 발현을 유도시킨 대조 군에 비해 톳 에탄올 추출물을 $500 \mu \mathrm{g} / \mathrm{ml}$ 의 농도로 처리하였 을 때 $\mathrm{iNOS}$ 발현이 $82 \%$ 저해되어 표준물질인 saponin $50 \mu$ $\mathrm{g} / \mathrm{ml}$ 농도와 유사한 저해효과를 나타냈고, $50 \mu \mathrm{g} / \mathrm{ml}$ 의 농도 로 처리하였을 때 iNOS 발현이 $42 \%$ 저해되어 saponin 0.5 $\mu \mathrm{g} / \mathrm{ml}$ 의 농도보다 높은 저해효과를 나타냈다(Fig. 7). 또한, 톳 수층 분획물을 $500 \mu \mathrm{g} / \mathrm{ml}$ 의 농도로 처리하였을 때 iNOS 발현이 $80 \%$ 저해되어 동일 농도의 톳 에탄올 추출물을 처리하 였을 때와 유사한 저해효과를 나타냈다(Fig. 7). 또한, 톳의 부 탄올, 헥산 및 메탄올 분획물들을 $500 \mu \mathrm{g} / \mathrm{ml}$ 의 농도로 처리하 였을 때 iNOS 발현이 각각 $70 \%, 62 \%, 65 \%$ 저해되어 표준물질 인 saponin $50 \mu \mathrm{g} / \mathrm{ml}$ 의 농도와 유사한 저해효과를 나타냈다 (Fig. 7). 한편, 톳 에탄올 추출물 및 분획물들을 $5 \mu \mathrm{g} / \mathrm{ml}$ 이하 의 농도로 처리하였을 때에는 LPS 유도성 $\mathrm{iNOS}$ 발현을 거의 저해하지 못하는 것으로 나타났다(Fig. 7). 이 결과로, 톳 에탄 올 추출물 및 수층 분획물이 LPS 유도성 iNOS 발현을 효과적 으로 저해할 수 있는 것을 확인할 수 있었다. 


\section{References}

1. Cabanes, J., Chazara, S. and Garcia, C. F. 1994. Kojic acid, a cosmetic skin whitening agent, is a slow-binding inhibitor of catecholase activity of tyrosinase. J. Pharm Pharmacol. 46, 982-985.

2. Chabrier, P. E. and Auguest, M. 1999. Nitric oxide synthases: targets for therapeutic strategies in neurological diseases. Cell Mol. Life Sci. 55, 1029-1035.

3. Cho, J. S. 1988. Food materials, Gijeon, Seoul, Korea pp. 336-336.

4. Chung, M. J., Walker, P. A., Brown, R. W. and Hogstrand, C. 2005. Zinc-mediated gene expression offers protection against $\mathrm{H}_{2} \mathrm{O}_{2}$-induced cytotoxicity. Toxicol. Appl. Pharmacol. 205, 225-236.

5. Ha, B. J. 2001. Cosmeceuticals. Shingwang Co, Seoul, Korea pp. $12-15$

6. Ha, S. E., Kim, H. D., Park, J. K., Chung, Y. O., Kim, H. J. and Park, N. B. 2009. Melanogenesis inhibition effect of Rosa multiflora extracts in B16 melanoma cells. Kor. J. Plant Res. 22, 317-322.

7. Han, J. Y., Sung, J. H., Kim, D. J., Jeong, H. S. and Lee, J. S. 2008. Inhibitory effect of methanol extract and its fractions from grape seeds on mushroom tyrosinase. J. Kor. Soc. Food Nutr. 37, 1679-1683.

8. Hurch, F. C., Meade, J. B., Treanor, R. E. and Whinna, H. C. 1989. Antithrombotic activity of fucoidin with heparin cofactor II, antithrombin III and thrombin J Biol. Chem. 6, 361-375.

9. Iwata, M., Corn, T., Iwata, S., Everett, M. A. and Fuller, B. B. 1990. The relationship between tyrosinase astivity and skin color in human foreskins. J. Invest. Dermatol. 95, 9-15.

10. Jee, S. O. 2009. Antioxidant activities and whitening effect of the Mulberry (Morus alba L.) root bark extracts. Kor. J. Plant Res. 22, 145-151.

11. Jang, M. J., Cheon, S. J., Kim, H. Y., Kwoen, D. J., Kim, H. Y., Kim, S. H. and Lee, J. T. 2011. The anti-wrinkle and whitening effect of extracts of Castanea crenata inner shell. J. Life Sci. 21, 734-738.

12. Jeong, M. H., Kim, S. S., Kim, J. S., Lee, H. J., Choi, G. P. and Lee, H. Y. 2010. Skin whitening and skin immune activities of different parts of Acer mono and Acer okamotoanum J. Kor. For. Soc. 99, 470-478.

13. Jung, B. M., Ahn, C. B., Kang, S. J., Park, J. H. and Chung, D. H. 2001. Effects of Hizikia fusiforme extraction lipid metabolism and liver antioxidative enzyme activities in triton-inducced hyperlipidemic rats. J. Kor. Soc. Food Sci. Nutr. 30, 1184-1189.

14. Jung, S. W., Lee, N. K., Kim, S. J. and Han, D. 1995. Screening of tyrosinase inhibitor from plants. Kor. J. Food Sci. Technol. 27, 891-896.

15. Kim, H. S., Choi, E. O., Park C., Choi, Y. H., Hyun, S. K. and Hwang, H. J. 2011. Effect of Hizikia fusiformis extracts on antioxidant enzyme activity and vitamin E concentration in rats. J. Kor. Soc. Food Sci Nutr. 40, 1556-1561.
16. Kim, K. I., Seo, H. D., Lee, H. S., Jo, H. Y. and Yang, H. C. 1998. Studies on the blood anticoagulant polysaccharide isolated from hot water extracts of Hijikia fusiforme. J. Kor. Soc. Food Sci. Nutr. 27, 1204-1210.

17. Kim, M. H., Jeon, M. J., Park, M. R., Lee, S. W., Hwang, H. J., Jang, H. J., Kang, M. S., Kim, B. K., Choi, S. T., Park, M. Y. and Lee, S. H. 2011. Purification of peat moss extract using a supercritical $\mathrm{CO}_{2}$ and verification of its biological activities. Kor. J. Biotechnol. Bioeng. 26, 459-464.

18. Kim, N.-Y., Jang, H., Lee, D.-G., Jang, M.-K., Lee, S. W., Jeon, M. J., Kim, M., Kim, S. G. and Lee, S.-H. 2011. Establishment of in vitro detection system for iNOS expression and verification of suppressive effect by pine needle extract. $K S B B$ J. 26, 172-176.

19. Kim, S. A., Kim, J., Woo, M. K., Kwak, C. S. and Lee, M. S. 2005. Antimutagenic and cytotoxic effects of ethanol extracts from five kinds of seaweeds. J. Kar. Soc. Food Sci. Nutr. 34, 451-459.

20. Kim, T. K., You, J. K., Kim, J. M., Baek, J. M., Kim, H. S., Park, J. H. and Choe, M. 2010. Antioxidant and whithening effects of Sorbus commixta HEDL cortex extract. J. Kor. Soc. Food Sci. Nutr. 39, 1418-1424.

21. Kligman, D. 2000. Cosmeveuticals. Dermatol. Clin. 18, 609-615.

22. Kwak, J. H., Kim, Y. H., Chang, H. R., Park, C. W. and Han, Y. H. 2004. Inhibitory effect of gardenia fruit extracts on tyrosinase activity and melanogenesis. Kor. J. Biotechnol. Bioeng. 19, 437-440.

23. Lim, S. B., Kim, S. H., Ko, Y. H. and Oh, C. K. 1995. Extraction yields of Hizikia fusiforme and Aloe vera Linne by supercritical carbon dioxide and antimicrobial activity of their extracts. Kor. J. Food Sci. Technol. 27, 68-73.

24. Lee, H. B., Bai, S. and Chin, J. E. 2005. Inhibitory effect of Lithospermum erythrorhizon extracts on melanin biosynthesis. J Kor. Soc. Food Sci. Nutr. 34, 1325-1329.

25. Lee, H. S., Cho, H. J., Lee, K. W., Park, S. S., Seo, H. C. and Suh, H. J. 2010. Antioxidant activities and melanogenesis inhibitory effects of Terminalia chebula in B16/F10 melanoma cells. J. Kor. Soc. Food Sci. Nutr. 15, 213-220.

26. Lee, S. M. 2011. Effects of Angelica gigantis herbal acupuncture extracts on the elastase activity and DPPH and NO scavenging activities. Thesis, Daegu Haany University.

27. Lee, S. W., Jang, M. K., Kim, N. Y., Jang, H. J., Lee, D. G., Kim, M. H. and Lee, S. H. 2010. The evaluation of the phytoestrogen activities from sea algae. J. Life Sci. 20, 1807-1811.

28. Lowenstein, C. J., Alley, E. W., Raval, P., Snowman, A. M., Synder, S. H., Russell, S. W. and Murphy, W. J. 1993. Macrophage nitric oxide synthase gene: two upstream regions mediate induction by interferon gamma and lipopolysaccharide. Proc. Natl. Acad Sci. USA 90, 9730-9734.

29. Seo, E. J., Hong, E. S., Choi, M. H., Kim, K. S. and Lee, S. J. 2010. Antioxidant and skin whitening effects of Rhamnus yoshinoi extracts. Kor. J. Food Sci. Technol. 42, 750-754.

30. Seo, S. Y. 2001. Screening of tyrosinase inhibitors from oriental herbs. Kor. J. Plant Res. 14, 32-37. 
31. Shin, J. Y. 2001. Screening of natural products that have activities against skin-aging. Kor. J. Food Nutr. 14, 568-572.

32. Solano, F., Briganti, S., Picardo, M. and Ghanem, G. 2006. Hypopigmenting agents: an updated review on biological, chemical and clinical aspects. Pigment Cell Res. 19, 550-571.

33. Tomita, K., Oda, N., Kamel, M., Miyaki, T. and Oki, T. 1990. A new screening method for melanin biosynthesis inhibitors using Streptomyces bikiniensis. J. Antibiotics 12, 1601-1605.

34. Tsao, L. T., Lee, C. Y., Huang, L. J., Kuo, S. C. and Wang, J. P. 2002. Inhibition of lipopolysaccharide-stimulated nitric oxide production in RAW 264.7 macrophages by a synthetic carbazole, LCY-2-CHO. Biochem Pharmacol. 63, 1961-1968.

35. Vodovotz, Y., Russell, D., Xie, Q. W., Bogdan, C. and
Nathan, C. 1995. Vesicle membrane association of nitric oxide synthase in primary mouse macrophage. J. Immund. 154, 2914-2925.

36. Wendel, A. and Feuerstein, S. 1981. Drug-induced lipid peroxidation in mice-1. Modulation by monooxygenase activity, glutathione and selenium status. Biochem Pharmacol. 30, 2513-2530.

37. Yoon, N. Y., Eom, T.-K., Kim, M.-M. and Kim, S.-K. 2009. Inhibitory effect of phlorotannins isolated from Ecklonia cava on mushroom tyrosinase activity and melanin formation in mouse B16F10 melanoma cells. J. Agric. Food Chem 57, 4124-4129.

\section{초록 : 톳(Hizikia fusiformis) 에탄올 추출물 및 분획물의 미백활성}

전명제 ${ }^{1} \cdot$ 김미향 ${ }^{2} \cdot$ 장혜지 ${ }^{1} \cdot$ 이승우 ${ }^{1}$ 김재훈 ${ }^{3} \cdot$ 김형석 ${ }^{3} \cdot$ 이상현 ${ }^{1}$ *

( ${ }^{1}$ 신라대학교 일반대학원 생명공학과, ${ }^{2}$ 신라대학교 식품영양학과, ${ }^{3}$ (주)해림파메틱

멜라닌 생합성은 tyrosinase의 효소적 산화반응에 의해 일어난다. 톳(Hizikia fusiformis)의 미백효과를 검증하 기 위하여 메탄올, 헥산, 부탄올 및 물을 용매로 이용한 분획과정을 통해 톳 에탄올 추출물로부터 분획물을 제 조하였다. 에탄올 추출물과 분획물들을 대상으로 B16F10 흑색종 세포에서 tyrosinase 활성 저해효과 및 멜라닌 생합성 억제효과를 평가하였다. 생쥐의 에탄올 추출물 및 수층 분획물은 미백효과를 나타냈지만, 세포독성은 나 타내지 않았다. 에탄올 추출물은 시료들 중에서 가장 높은 미백활성을 보였다. 에탄올 추출물은 $100 \mu \mathrm{g} / \mathrm{ml}$ 의 농 도에서 arbutin $10 \mu \mathrm{g} / \mathrm{ml}$ 의 활성보다 높은 저해활성을 보였으나, kojic acid $10 \mu \mathrm{g} / \mathrm{ml}$ 의 활성보다는 낮은 저해 활성을 보였다. 또한, 메탄올, 헥산, 부탄올 및 수층 분획물은 $100 \mu \mathrm{g} / \mathrm{ml}$ 의 농도에서 arbutin $10 \mu \mathrm{g} / \mathrm{ml}$ 의 활성 과 유사한 저해활성을 보였다. 항산화 활성은 L-ascorbic acid를 양성 대조군으로 하여 수치를 비교하여 나타냈 다. 에탄올 추출물 및 수층 분획물의 DPPH 라디칼 소거활성은 다른 시료들보다 비교적 높게 나타났다. 또한, 에탄올 추출물및 수층 분획물은 $500 \mathrm{\mu g} / \mathrm{ml}$ 의 농도에서 LPS에 의해 유도된 $\mathrm{iNOS}$ 발현을 각각 82 와 $80 \%$ 감소시 켰다. 이러한 결과들로 톳의 에탄올 추출물과 수층 분획물은 미백효과 및 피부 보호효과를 가지는 화장품 소재 로 이용 가능할 것으로 기대된다. 